\title{
Late Holocene Subsistence Practices Among Cis-Baikal Pastoralists, Siberia: Zooarchaeological Insights from Sagan-Zaba II
}

\begin{abstract}
$\boldsymbol{\Delta} \cdot \boldsymbol{\Delta} \cdot \boldsymbol{\Delta}$
TATIANA NOMOKONOVA, ROBERT J. LOSEY, ANDRZEJ WEBER, OL'GA I. GORIUNOVA, AND ALEKSEI G. NOVIKOV
\end{abstract}

\section{INTRODUCTION}

FOR MANY PEOPLE THE TERM SibERIA CONJURES UP IMAGES of vast tracts of tundra and boreal forests, but in truth much of its southern reaches consist of steppe and forest-steppe environments that are in effect northern extensions of Central Asia eco-regions. Long-term human history in these southern regions is also strongly interwoven with that of Central Asia, especially with the development and expansion of nomadic pastoralism over the last several thousand years. The Lake Baikal region of eastern Siberia is no exception to either of these patterns. This region has a fairly extensive Holocene archaeological record of both hunter-gatherers and pastoralists, both in terms of mortuary remains and habitation sites. Most archaeological research on pastoralist sites around Lake Baikal has focused on cultural historical periodization and mortuary analyses, but very little work has been directed at pastoralists' subsistence practices. One could get the impression that pastoralism simply arrived here and then remained unchanged until the late historic period, despite several episodes of widespread population displacements and other significant culture changes. This paper represents one of the first attempts at using both modern recovery techniques and zooarchaeological quantification measures to understand temporal trends in nomadic pastoralist subsistence patterns in the Baikal region. This archaeological data, in combination with ethnographic and historic material on more recent Baikal populations, reveals long-term trends in the unique nature of late Holocene subsistence practices here, including the regular use of the lake's freshwater seals and fishes by pastoralist groups.

Tatiana Nomokonova, Robert J. Losey, and Andrzej Weber are all affiliated with the Department of Anthropology, University of Alberta, Edmonton, Canada, where Ms. Nomokonova is a Ph.D. candidate, Dr. Losey is an Associate Professor, and Dr. Weber is a Professor. Dr. Ol'ga I. Goriunova and Dr. Aleksei G. Novikov are affiliated with the Irkutsk Laboratory of Archaeology and Paleoecology of Institute of Archaeology SO RAN and Irkutsk State University. Dr. Ol'ga I. Goriunova is a Leading Scientific Researcher, Dr. Aleksei G. Novikov is a Minor Scientific Researcher. 


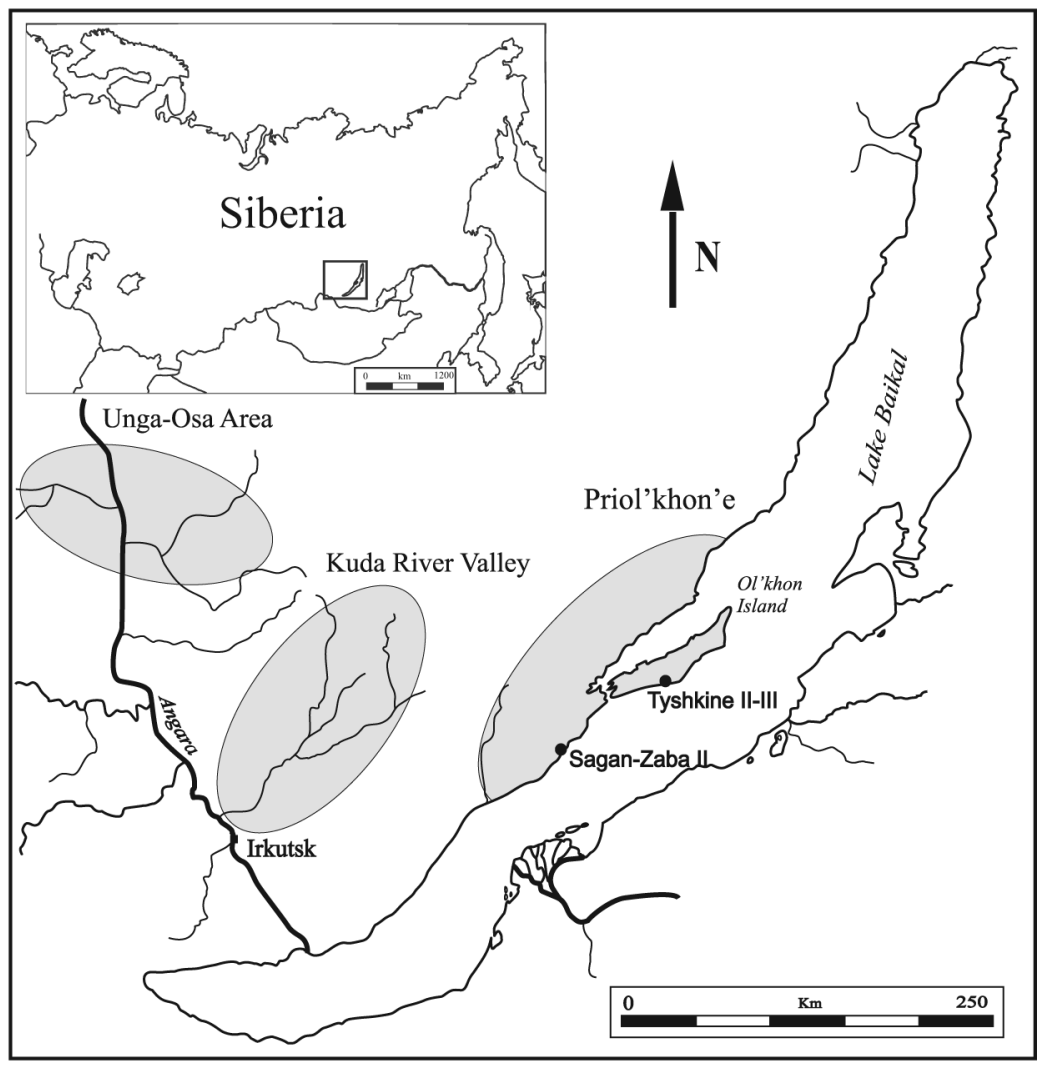

Fig. 1. Map of Cis-Baikal and archaeological sites within Priol'khon'e. Inset box shows Lake Baikal's position within Siberia, Russia.

Nomadic pastoralists first arrived in the Cis-Baikal region of eastern Siberia roughly 3000 years ago, and eventually displaced or partially absorbed local hunting and gathering populations. At least two broad processes seem to have contributed to these population movements. First is the formation of large pastoralist polities outside of Cis-Baikal (see Grousset 2005), which displaced competitors at their margins northward toward the Lake Baikal area or expanded their own territories to this region. Second was the aridization of Cis-Baikal which brought about the formation of three steppe patches in the region roughly 4000 years ago (Goriunova and Vorob'eva 1986; Kharinskii 1995; Vorob'eva and Goriunova 1997). These patches (Fig. 1) became focal regions for pastoralists, who depended heavily on animal husbandry and periodic shifting of grazing areas (Kharinskii 1995).

Here we specifically focus on long-term trends in subsistence practices of pastoralist groups inhabiting Cis-Baikal, the region west of Lake Baikal including the islands and western shores of the lake itself. Our primary geographic focus is the Priol'khon'e microregion of Cis-Baikal, the steppe patch directly adjacent to the lakeshore (Fig. 1). Archaeological surveys and excavations have revealed a variety of late Holocene sites in Priol'khon'e, including cemeteries, ritual construc- 
tions, habitation sites, and fortified settlements (Goriunova and Svinin 1995, 1996, 2000). One of the habitation sites recently excavated by the interdisciplinary Baikal Archaeological Project (BAP) is Sagan-Zaba II (hereafter simply SaganZaba) located on the western shore of Lake Baikal within Priol'khon'e (Goriunova et al. 2007a). This site has produced just under 80,000 faunal remains with almost 30 percent deriving from late Holocene deposits. As one of the few stratified late Holocene habitation sites in the region, it offers a unique opportunity to examine diachronic patterns in diet and subsistence of local pastoralists. In addition, the assemblage described here was excavated using modern recovery techniques that allowed for the collection of whole categories of faunal remains (fish, small mammals) typically under-represented (or not represented at all) in the region's previously excavated assemblages. The faunal data we present here speak to not just trends in the use of domesticated animals but also the exploitation of wild fauna by the region's pastoralists. Moreover, while numerous English language publications on Cis-Baikal Middle Holocene hunter-gatherers have appeared in recent years (Weber et al. 2002 and references therein), this is one of the first non-Russian-language papers on the region's late Holocene archaeological record. Given the dearth of English-language archaeological material on this time period and area, we begin with a brief review of its late Holocene archaeological record.

\section{PASTORALIST CULTURE HISTORY IN CIS-BAIKAL}

Nomadic pastoralist populations of the Eurasian steppes, including (but not limited to) the Scythians, Hsiung-nu, and various Turkic and Mongolian groups have a presence in the archaeological record in Cis-Baikal extending back at least 3000 years (Pletneva 1982), particularly on the west coast of Lake Baikal. Sometime during the late Bronze Age, nomadic pastoralists began to arrive in CisBaikal from southern Trans-Baikal and northern Mongolia (Kharinskii 2001a; Tsybiktarov 1999). These population movements initially did not result in the total displacement of local hunter-gatherer groups, which continued to inhabit some portions of Cis-Baikal, particularly those areas least suitable for pastoralism (Okladnikov 1959). However, by the beginning of the late Iron Age ( $\sim$ A.D. 600), the majority of hunter-gatherer groups appear to have been pushed from most of southern and central Cis-Baikal and inhabited only its far northern and western regions.

The culture history of pastoralists in Cis-Baikal primarily has been constructed around mortuary traditions (Kharinskii 2001b) because few habitation sites in the region contain stratified cultural deposits (Nomokonova 2003). On the other hand, late Holocene cemeteries and ritual constructions here are relatively common and many have been extensively excavated (e.g., Aseev 1980; Dashibalov 1995; Kharinskii 2001b; Svinin 1976; Turkin 2004). The first migration of pastoralists to Cis-Baikal, probably originating from Trans-Baikal (located east-southeast of the lake), is identified in Priol'khon'e through the presence of "slab graves" dating to the late Bronze/early Iron Ages, from 1400-300 B.C. (Kharinskii 2005). In broader Central Asia, this period is roughly associated with the ScythianSarmatian time (Grousset 2005). Locally, this archaeological culture or tradition is known as the "slab grave constructors" or Buturkhei period (all period or tradi- 
tion names here are derived from type site names). This period sees the first introduction to the region of domesticated horses, sheep, goats, and cattle as well as iron tool production (Kharinskii 2005).

The second apparent migration of pastoralists to Cis-Baikal is associated with the formation of the Hsiung-nu Empire in Mongolia around 300 B.C. (Grousset 2005; Ishjamts 1994). Several researchers have suggested that the expansion of the Hsiung-nu pushed neighboring southern Siberian groups northward toward the Lake Baikal coast (Goriunova and Pudovkina 1995; Kharinskii 2005). In Priol'khon'e and broader Cis-Baikal the appearance of these nomadic groups is seen in the Elga mortuary tradition dated from 300 B.C.-A.D. 500/800 (Goriunova and Pudovkina 1995; Kharinskii 2005). Though Elga materials have been identified in Cis-Baikal, these mortuary sites are not nearly as extensive as those seen in Trans-Baikal (Tsybiktarov 1998, 1999) or other regions of southern Siberia (Oklandikov 1959), perhaps indicating that populations here were comparatively small.

The third set of events that led to significant cultural changes in Cis-Baikal and adjacent territories is the formation of Turkic states beginning with the Turk Khanate around A.D. 600 (Grousset 2005). The formation of these states appears to have resulted in the third major migration of pastoralists to the region. In CisBaikal, this period is marked by the arrival of populations known as Kurykane who were pastoral nomads, ironsmiths, and practiced small-scale agriculture (Svinin 1976). This population left a significant archaeological record of graves, ritual construction, fortified settlements, rock art, and habitation sites that are known as the Kurumchin archaeological culture of the Late Iron Age (A.D. 600/800-1400). The Kurykane were famous horsemen, warriors, and reportedly were known widely among steppe populations as producers of excellent horses (Dashibalov 1995).

The appearance of Mongols, including ancestors of modern Cis-Baikal populations known as Buriats, began in neighboring Trans-Baikal at A.D. 700 (Rumiantsev 1962). In Cis-Baikal the first graves of early Mongols appear significantly later, at A.D. 1100-1400. This period is referred to in the regional literature as the Early Mongolian Time (Imenokhoev 1992). The process of Mongolian penetration in Cis-Baikal appears to have been characterized by a period of coexistence followed later by assimilation and gradual replacement of the Kurykane, many of whom eventually settled far to the north-northwest.

\section{ZOOARCHAEOLOGY OF CIS-BAIKAL PASTORALISTS}

Although archaeological excavations have been conducted in Cis-Baikal for over a century, systematic zooarchaeological research did not occur until very recently. Typically, collections were examined by palaeontologists and the reports produced were patchy and limited to providing lists of taxa present, with little in the way of quantification. In addition, recovery techniques often have been inadequate for proper zooarchaeological analyses-sieves have rarely been employed in field recovery resulting in severe under-representation of small-bodied fauna (Nomokonova et al. 2007). Given these limitations, most statements about trends in subsistence patterns and diets during the late Holocene have been conjectural 
and are typically not supported by well-described data sets; existing data should be evaluated with a good deal of caution.

A number of cemeteries in Cis-Baikal are reported to contain remains of domesticated animals in association with human skeletons (Aseev 1980; Kharinskii 2001b; Nikolaev 2004). The earliest of these belongs to the slab graves of the late Bronze/early Iron Age (Kharinskii 1995), though specific taxonomic identifications are rarely provided (Turkin 2004). However, some information is available on species found in slab graves from nearby Trans-Baikal, with commonly mentioned animals including horse, sheep, and more rarely cattle (Tsybiktarov 1999). Most such research in Cis-Baikal has focused on burials of horses, cattle, and sheep in medieval graves from the Kuda Valley directly west of our study area (Fig. 1; Ermolova 1978; Nikolaev 2004). These ritual deposits demonstrate the presence of specific domesticates in Cis-Baikal at various points in the late Holocene, but we believe they likely reveal more about cosmology and status than they do about trends in subsistence patterns and diets, which are perhaps best evidenced by faunal remains deriving from non-ritual contexts.

However, decades of archaeological research has shown that very few habitation sites in Cis-Baikal contain deposits of faunal remains and other archaeological materials dating to the late Holocene. Among these are a few major probable Turkic "medieval" (how all of the following sites were dated was unspecified) winter settlements in the Unga, Kuda, and Angara River Valleys west of our study area (Dashibalov 1995; Ermolova 1978; Nikolaev 2004). Faunal remains from these sites were analyzed by paleontologists and include 6303 remains from the Unga or Balagansk settlement said to date from A.D. 800-1100 (Ermolova 1978), 1144 remains from Mankhai fortified settlement possibly dating from A.D. 800-1000 (Kasparov 1991), and 17,512 remains from Totok settlement (unspecified medieval-period occupation; Klement'ev and Nikolaev 2007). The lists of taxa recovered from these sites are quite similar and include domesticated animals such as cattle, horse, caprines (mainly sheep but some goats), and a few remains of camel, kulan, and dog. Wild taxa at the sites are dominated by roe deer and red deer, with trace amounts of moose, auroch, reindeer, musk deer, fox, wolf, bear, steppe polecat, and marmot also being identified (Ermolova 1978; Kasparov 1991; Klement'ev and Nikolaev 2007). ${ }^{1}$

In the Priol'khon'e, traces of late Holocene pastoralist occupation can be found in many coves along Lake Baikal, but most of these sites consist of deflated deposits from multiple time periods. Furthermore, such sites typically have very poorly preserved faunal remains, and what has been recovered has typically not been analyzed (Nomokonova 2005; Nomokonova and Goriunova 2000). Prior to the current study, the only analyzed late Holocene faunal assemblage in Priol'khon'e is that from Tyshkine II/III located on the east coast of Ol'khon Island. Late Holocene materials here, however, are not well dated and could only be assigned to two broad time periods, namely the "Transition to Bronze Age" and Iron Age (Goriunova et al. 2007b). Faunal remains found in these layers included only 1381 specimens, with 65 percent of these being unidentifiable fragments. Here again, no sieving was employed during excavation and the assemblage is almost entirely composed of remains from large-bodied fauna. Ovodov, a paleontologist, identified these remains in the 1970 s, and results were reported by Goriunova et al. 
(2007). Identified late Holocene materials here include a few bones of domesticates (caprines, horse, cattle), red deer, and seal (almost $7 \%$ of the total), with much of the unidentified materials being placed in the category of large and small artiodactyls $(26 \%)$. Notably, the Tyshkine sites are in a very similar setting to our study site-they are located directly on the shore of the open lake adjacent to very deep waters, and the surrounding landscape consists of rolling steppe and forest-steppe hills. This meager assemblage provides the only late Holocene subsistence data from Priol'khon'e for comparison with the data presented below.

\section{CIS-BAIKAL PASTORALISTS AND THEIR ANIMALS}

Before examining the new faunal data from Sagan-Zaba, we present an overview of diet and subsistence practices evidenced in ethnohistorical and archaeological data from throughout Cis-Baikal. Historical and ethnohistorical documents of relevance date largely from the eighteenth to the beginning of the twentieth century prior to the Soviet period (Batueva 1989; Curtin 1909; Galdanova 1992; Georgi 1777; Viatkina 1969; Zhambalova 2004). Archaeological information on Kurykane and early Mongols is largely taken from Dashibalov (1995) and Aseev (1980), with useful overviews in Kharinskii $(2001 a, b)$.

While our research area was home to a mosaic of different nomadic groups during the late Holocene, it has been argued that all populations here shared a general pattern of animal-based subsistence practices (Kharinskii 2005). These shared subsistence practices most likely have persisted in some form because the environment of Priol'khon'e and broader Cis-Baikal is characterized by relatively marginal pastures and poor soils (compared to regions to the south) as well as short growing seasons, all of which limited agricultural activities. Foremost among the shared subsistence practice of the pastoralist groups in this region were the species of animal raised and products produced from them. The Buriats, and perhaps also earlier pastoralists in Cis-Baikal, used cattle, sheep, and goats for producing meat, milk, and wool, while horses and oxen were primarily employed for traction and transport, but sometimes also were eaten. Like many other Eurasian steppe pastoralists (Barfield 1993), the Buriats consider horse meat and milk as delicacies (Zhambalova 2004).

Cis-Baikal pastoralists raised herds composed of five main species suitable for the region. They include horses, cattle, sheep, goats, and occasionally camels (Batueva 1989; Galdanova 1992; Pallas 1788). Among these animals, the horse is (and was) the key animal in culturally defining Eurasian steppe pastoralists, forming a major element of their identity (Anthony 2007; Curtin 1909; Georgi 1777). Furthermore, horses were well-known symbols of warfare, wealth, trade, and spiritual concerns throughout the steppe zone (Dashibalov 1995; Nikolaev 2004). More locally, horses were historically of great importance among the Kurykane, who bred and traded them across a broad region.

Sheep and goats were probably the most important animals in local diets due to their rapid reproduction in comparison to cattle and horse and ability to consume vegetation that is marginal for most other domesticates (Barfield 1993; Zhambalova 2004). Sheep historically accounted for approximately 50-60 percent of all animals raised by the Buriats inhabiting Ol'khon Island (Zhambalova 2004:97; data not available for other steppe regions of Cis-Baikal). Unlike cattle, horses 
and sheep were more highly favored here because horses can use their hooves to forage under snow while sheep (and goats) can follow after them to feed in exposed areas. The relative abundance of cattle here appears to have increased toward the beginning of the twentieth century, perhaps as facilities for providing winter forage were developed and sedentism increased (Zhambalova 2004:97).

Mobility and herding practices in the study area involved mixed herds and periodic migration from pasture to pasture. Mobility was high year-round, but during winter use of permanent settlements was common in some areas (Batueva 1989). With Russian migration to this region of Siberia, mobility was reduced to only two major residential shifts per year for most groups (Zhambalova 2004). A few probable Kurykane winter settlements have been identified by archaeologists in steppe patches on tributaries of the Angara River (Dashibalov 1995), and some seasonally occupied camps have been identified both archaeologically and historically on the west coast of Lake Baikal. Pastoral nomads of the Lake Baikal region were also involved in small-scale agriculture that supplemented the pastoral economy. Yields from these practices were likely very limited due to the relatively poor soils, aridity, and short growing season, but there is both archaeological and historic evidence that Baikal pastoralists grew barley and millet (Dashibalov 1995). However, this does not appear to be the case in Priol'khon'e, which is markedly more arid than other parts of Cis-Baikal. Here pastoralism historically was significantly supplemented by fishing and the hunting of cervids, fur-bearing mammals, and seals (Mikhailov 2006). Given this general information on subsistence practices in Cis-Baikal, we now turn to an examination of the newly recovered faunal remains from Sagan-Zaba.

\section{SAGAN-ZABA II AND ITS FAUNA}

Sagan-Zaba is situated on the west coast of central Lake Baikal (Figs. 1, 2). The small cove and shoreline near the site are well known for their nearly vertical white cliffs that feature extensive prehistoric rock art (Okladnikov 1974). These ancient images are still considered sacred by the local Buriat population who in the early historic period visited the site twice a year to honor the "master of the drawings" (Zhambalova 2000). Stratified Holocene habitation deposits are found throughout the floor of the short U-shaped valley backing the cove, and the steep walls of the valley provide good shelter from winds in all directions except from the lake itself (Fig. 2). This location also allows good access to the lake's deep open waters, which are the preferred habitat of the Baikal seal (Phoca sibirica; Pastukhov 1993).

Archaeological materials at Sagan-Zaba were discovered and excavated in the 1970s by expeditions of the Institute of History, Philosophy, and Philology of Academy of Science of USSR from Novosibirsk, Russia (Aseev 2003; Okladnikov 1974; Ovodov and Panychev 1982). These excavations, which appear to have spanned around $40 \mathrm{~m}^{2}$, are only partially described in a few short papers, and collections from them are now missing. The reports indicate that cultural materials spanning from the Iron Age to the non-ceramic Neolithic (also known as Final Mesolithic) were recovered. Faunal remains were reportedly very abundant and dominated by seal during the Neolithic, but are documented only in a two-page report (Ovodov and Panychev 1982). Remains of domesticates were 


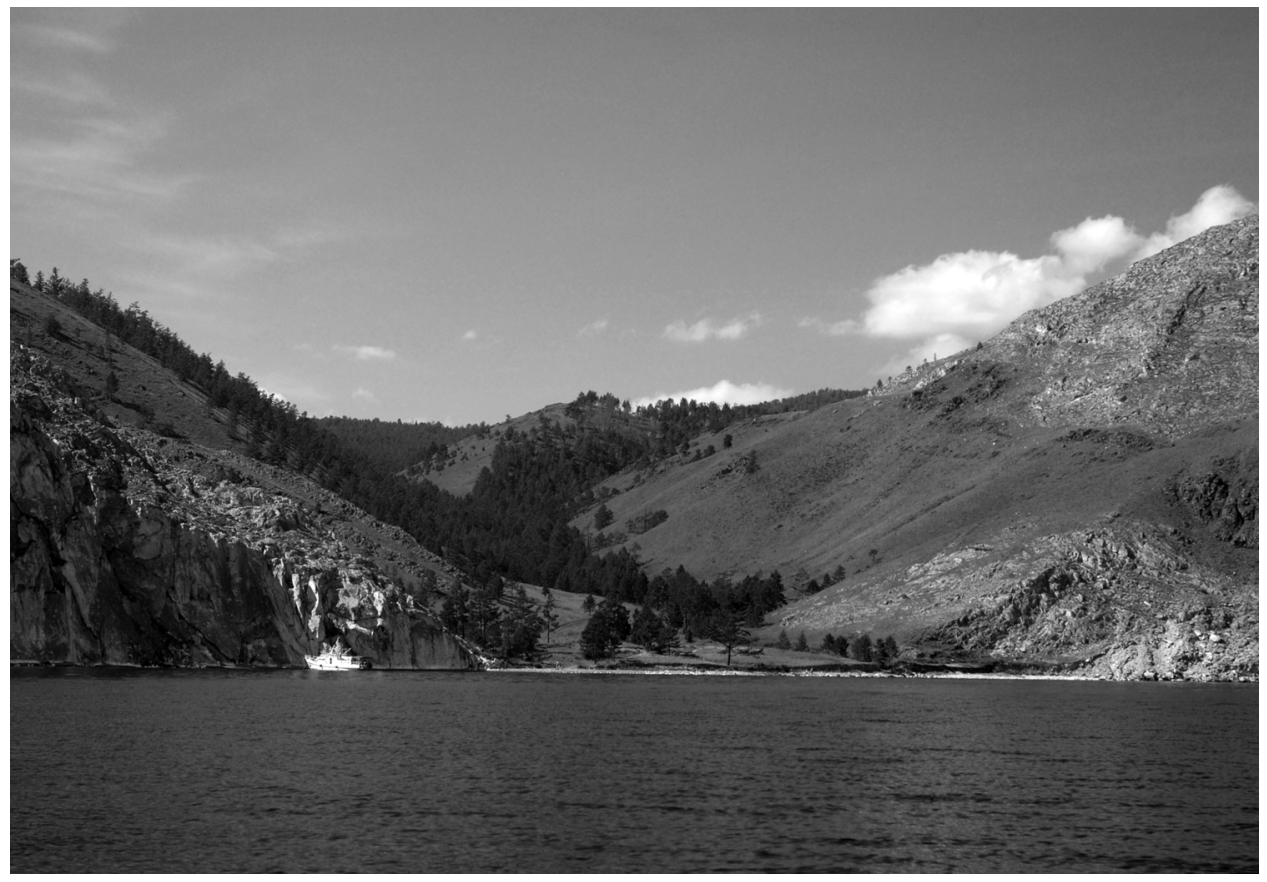

Fig. 2. Sagan-Zaba Cove, view from the southeast. (Photo by A. Weber)

also found, including cattle, sheep, goat, and horse. Weber et al.'s (1998) study of dentine layers in seal teeth recovered from the early excavations suggests Middle Holocene seal hunting occurred in late winter and early spring when the lake was ice-covered.

From 2006 to 2008, Sagan-Zaba was excavated by the Baikal Archaeological Project, a multinational research endeavor centered at the University of Alberta, Canada. Modern field recovery and recording methods (e.g., sieving of all deposits over $3 \mathrm{~mm}$ mesh, flotation for botanical remains, detailed stratigraphic studies, and total station artifact mapping) were applied throughout all phases of excavation. BAP's fieldwork in 2006 involved testing the cove through augering and small excavation blocks (trenches 1-4a, 5; Fig. 3) in order to determine the area of the valley most suitable for more extensive sampling (Goriunova et al. 2007a; Nomokonova et al. 2009). The northeastern portion of the valley within $\sim 8 \mathrm{~m}$ of the shoreline proved to have the deepest stratigraphy, best preserved organic materials, and densest cultural materials. Two trenches (4b and 4c; Fig. 3) totaling $\sim 67 \mathrm{~m}^{3}$ were excavated in this section of the site in 2007-2008 and produced $\sim 74,040$ faunal remains from 11 cultural layers spanning from the Mesolithic to the Early Mongolian Time (10,000-550 B.P.). The results of the faunal analyses in this paper are focused on the materials from the I-III cultural layers, all dating to the late Holocene.

Animal bones described below were generally scattered through the sediments and not in direct association with any features. However, remains of six hearths were found in the late Holocene layers. Most of these features were composed of slabs located in inclined or horizontal postions surrounding sediments containing 


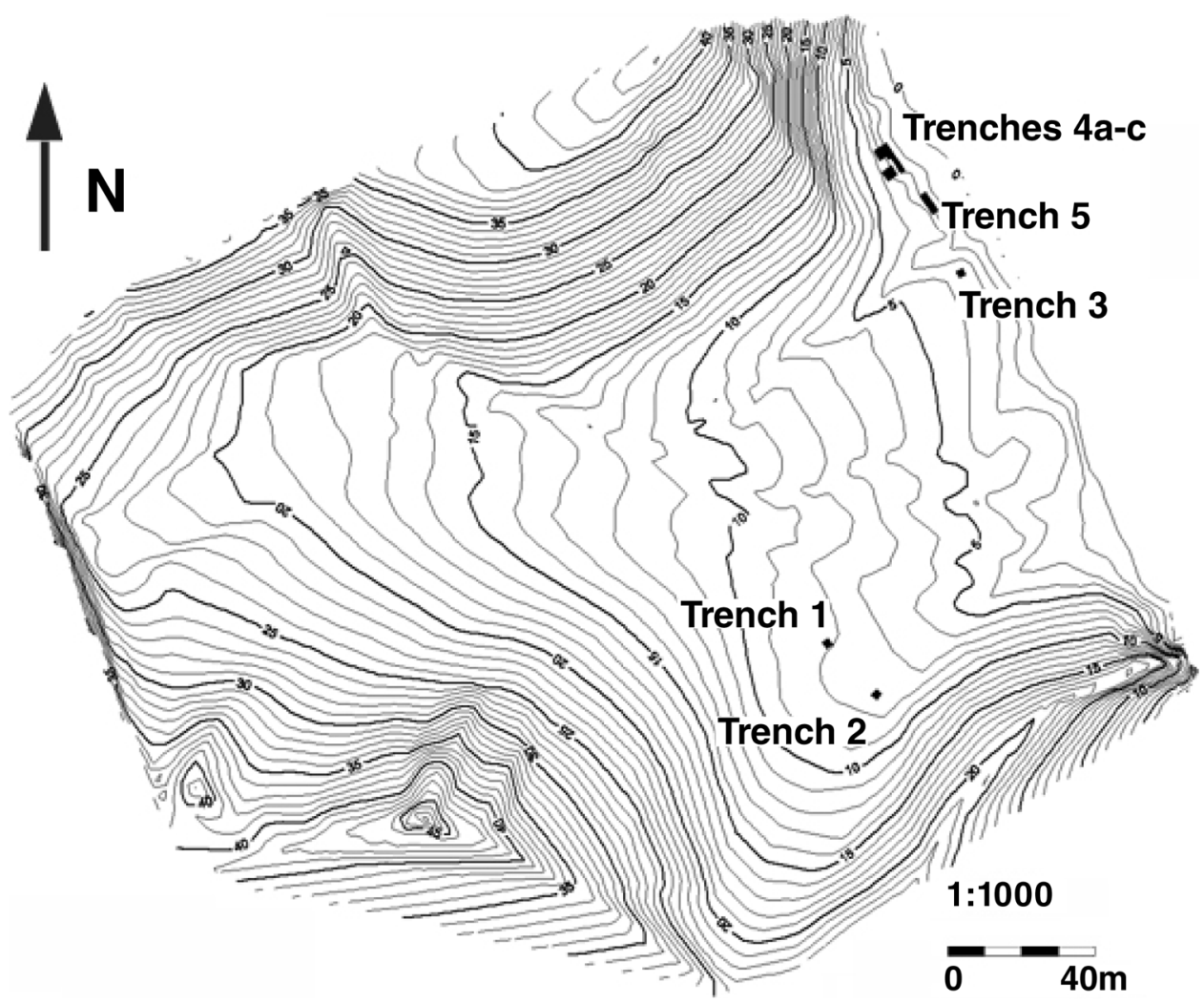

Fig. 3. Topographic plan of Sagan-Zaba Cove with areas excavated from 2006-2008 by the Baikal Archaeological Project indicated.

charcoal and oxidized sediment. Some artifacts and animal bones were found in the fill of these constructions and in the surrounding sediments.

The first evidence of domesticated animals at Sagan-Zaba Cove was found in Layer IIIB. Excavation of this layer produced 9293 cultural remains, with 7976 of these being animal remains. Artifacts recovered include a bronze awl, and stone knives, scrapers, arrowheads, and debitage; bone and antler tools include piercing implements, beads, a harpoon, point, needle case, and one arrowhead. Pottery fragments from a minimum of 25 vessels were found, including fragments with no decorative elements and those with stamped or incised elements characteristic of the Bronze Age. This layer seems to be a compression of different phases of the Bronze Age and may include archaeological materials of both hunter-gatherers and pastoralsits. Two radiocarbon dates on charcoal from this layer produced ages of $2600 \pm 145$ (SOAN-6593; 900-540 B.C.) and $3370 \pm 55$ (SOAN-7148; 1740-1570 B.C.) (all dates calibrated using Calib 5.0.1 (Stuiver et al. 2005), with margins of errors presented at 1 sigma).

Layer IIIA produced 8613 cultural remains, including 8247 animal remains. Artifacts recovered include a few iron tool fragments (Fig. 4: 3-5), among which are several awls and one pendant. Chipped stone scrapers and debitage, and pieces 
Table i. Late Holocene Faunal Remains from Sagan-Zaba II by Number of IDENTIFIED SPECIMENS (NISP)

\begin{tabular}{|c|c|c|c|c|c|c|}
\hline & & I & II & IIIA & IIIB & TOTAL \\
\hline TAXA & COMMON NAME & NISP & NISP & NISP & NISP & NISP \\
\hline \multicolumn{7}{|l|}{ Mammalia } \\
\hline Equus spp. & Horses & 6 & 29 & 25 & 3 & 63 \\
\hline Cervidae & Deer & 2 & 10 & 6 & 6 & 24 \\
\hline Cervus elaphus & Red deer & & 10 & 10 & 7 & 27 \\
\hline cf. Alces alces & Moose & & & 1 & & 1 \\
\hline Capreolus pygargus & Roe deer & 11 & 54 & 26 & 16 & 107 \\
\hline Bos spp. & Oxen and true cattle & 13 & 97 & 47 & 12 & 169 \\
\hline Caprinae & Goats and sheep & 19 & 67 & 58 & 22 & 166 \\
\hline Ovis aries & Domesticated sheep & & 7 & 5 & 5 & 17 \\
\hline Capra hircus & Domesticated goat & & 4 & & 1 & 5 \\
\hline Artiodactyla & Even-toed ungulates & 33 & 122 & 97 & 39 & 291 \\
\hline Phoca sibirica & Baikal seal & 55 & 119 & 112 & 416 & 702 \\
\hline Martes zibellina & Sable & & & 1 & & 1 \\
\hline Lutra lutra & Otter & & & & 1 & 1 \\
\hline Vulpes vulpes & Red fox & & 1 & & & 1 \\
\hline Carnivora & Undifferentiated carnivores & & 1 & & 1 & 2 \\
\hline Castor fiber & Beaver & & & & 1 & 1 \\
\hline Lepus timidus & Mountain hare & & & 2 & 3 & 5 \\
\hline Marmota spp. & Marmots & & 1 & & & 1 \\
\hline Citellus undulatus & Eurasian ground squirrel & 4 & 2 & 14 & 54 & 74 \\
\hline Muridae & Mice, rats, and relatives & 1 & 2 & 18 & 27 & 48 \\
\hline Rodentia & Undifferentiated rodents & & 14 & 37 & 31 & 82 \\
\hline Mammalia-unidentified & & 2406 & 6612 & 7225 & 6767 & 23,010 \\
\hline \multicolumn{7}{|l|}{ Aves } \\
\hline Emberizidae & Sparrows and relatives & & & 1 & & 1 \\
\hline Anas spp. & Dabbling ducks and teals & & & & 1 & 1 \\
\hline Buteo cf. buteo & cf. Common buzzard & & & & 1 & 1 \\
\hline Aves-unidentified & Birds & 1 & & 3 & 6 & 10 \\
\hline \multicolumn{7}{|l|}{ Pisces } \\
\hline Coregonus spp. & Whitefish/omul & & & 6 & 8 & 14 \\
\hline Thymallus articus & Grayling & & 1 & 2 & 1 & 4 \\
\hline Salmonidae & Grayling and whitefish & 2 & 29 & 428 & 363 & 822 \\
\hline Acispenser $b$. baicalensis & Baikal sturgeon & 2 & 1 & 5 & 28 & 36 \\
\hline Rutilis rut. lacustris & Siberian roach & & & 1 & & 1 \\
\hline Leuciscus leuc. baicalensis & Ide & & & 3 & 1 & 4 \\
\hline Cyprinidae & Carps & & & & 1 & 1 \\
\hline Perca fluviatilis & Eurasian perch & & & 2 & 5 & 7 \\
\hline Esox lucius & Northern pike & & 1 & & & 1 \\
\hline Pisces-unidentified & Fishes & 52 & 40 & 107 & 141 & 340 \\
\hline \multicolumn{7}{|l|}{ Mollusca } \\
\hline Mollusca & Undifferentiated mollusks & & & 1 & 4 & 5 \\
\hline Undifferentiated bone & & 184 & 12 & 4 & 4 & 204 \\
\hline Total & & 2791 & 7236 & 8247 & 7976 & 26,250 \\
\hline
\end{tabular}




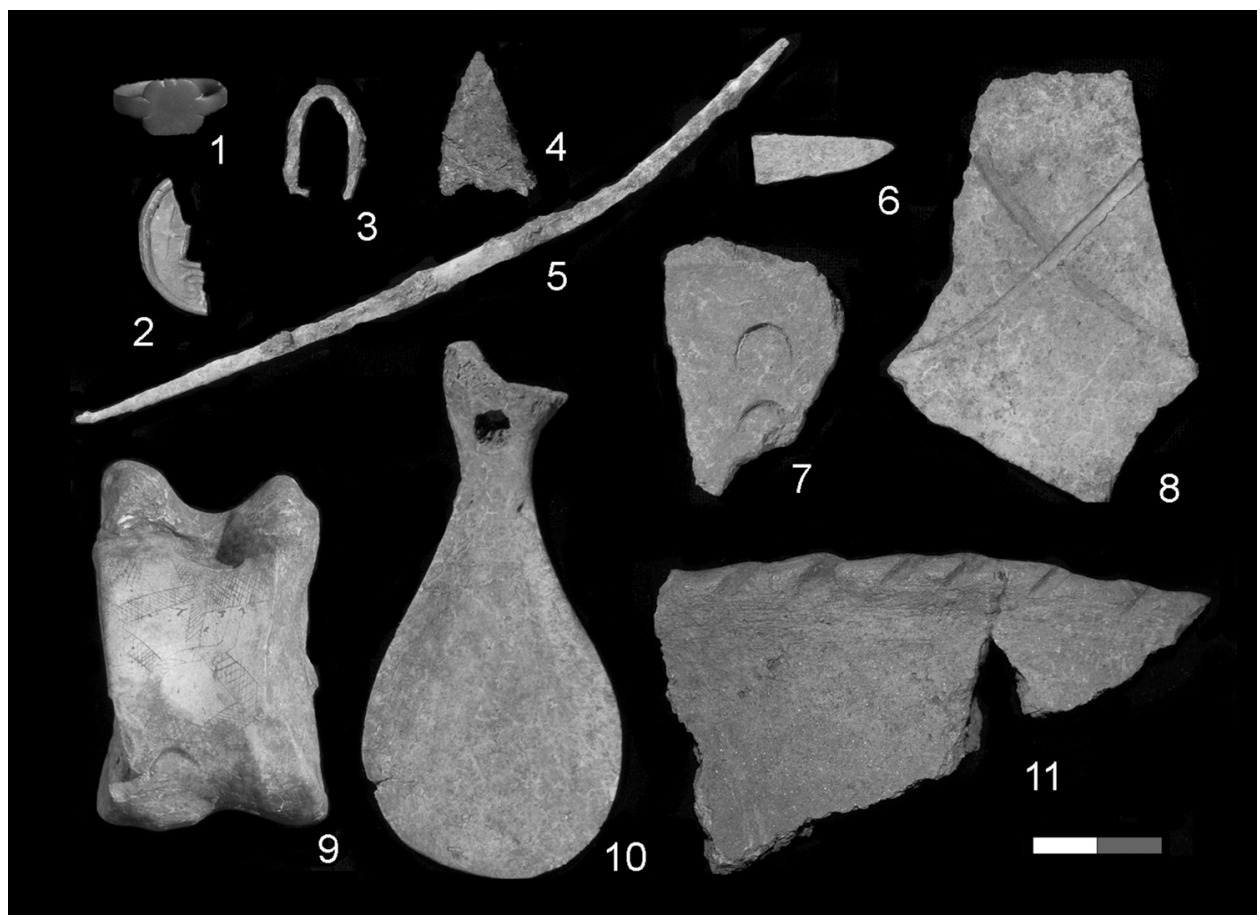

Fig. 4. Selected artifacts found in Layers IIIA, II, and I.

of birch bark with marks from stiching also were found. Bone implements include a spoon fashioned from a seal scapula (Fig. 4: 10), a roe deer astragalus with polished lateral sides, a point, and a polisher. Pottery fragments from at least 14 vessels were found with smooth-surfaced or corded exterior wall textures and footrings. The most common decoration on the pots are inclined notches on the rim, stamped applique bands, and rows of round impressions or holes sometimes associated with incised lines. These types of ceramics are typical of the transitional late Bronze/early Iron Age and early Iron Age (Goriunova and Novikov 1997). Two radiocarbon dates were produced on materials from this layer: $1985 \pm 35$ (SOAN-6592; 40-30 в.c.) and $2555 \pm 90$ (SOAN-7149; 810-700 в.с.).

Layer II appears to have cultural materials associated with the Kurykane period or late Iron Age (Nomokonova 2005). Excavation of this layer produced 7568 cultural remains, including 7236 animal remains. Artifacts include a few simple lithics implements, undifferentiated iron tool fragments (one is a knife fragment; Fig. 4: 6), and one fragment of a Chinese copper coin (Fig. 4: 2). Bone implements include an antler tool fragment, a decorated red deer astragalus (Fig. 4: 9), and a cattle horncore carved in a phallic shape. Ceramic fragments from at least 22 vessels were found. These are from smooth-surfaced pots with flat bases and thick walls, sometimes decorated by applique bands, and incised impressions (Fig. 4: 11) in combination with incised zigzags. One radiocarbon date of $1530 \pm 90$ (SOAN6591; A.D. 430-600) was obtained on this level.

Archaeological material from Layer I consists of only 2876 items, of which 2791 are faunal remains. Among the artifacts were a bronze ring or seal (Fig. 4: 
1), an iron tool fragment, undifferentiated lithics, and pottery fragments. The latter come from at least ten smooth-surfaced pots, many of which are typologically similar to those from Layer II. However, decorative elements are more variable here and include an arch design (Fig. 4: 8) and crescent-shaped impressions (Fig. 4: 7). These pottery decoration styles are common in the sites of Early Mongolian Time (Nomokonova 2005). A single radiocarbon date of $580 \pm 85$ (SOAN6590; A.D. 1300-1370) was produced on this layer. While this single radiocarbon date falls within the Early Mongolian Time, some of the pottery is typologically associated with the Kurykane. This might indicate a period of co-existence between the two groups or mixing of materials between layers I and II. Given the relatively small faunal assemblage from this layer, and the possibility of mixing of materials between Layers I and II, we combine the two in our following discussions and analyses.

The total late Holocene faunal assemblage from trenches $4 \mathrm{~b}$ and $4 \mathrm{c}$ at SaganZaba consists of 26,250 animal remains, 9.1 percent (2389 specimens) of which were identified at least to the family level (Table 1). Almost all faunal remains were analyzed using a comparative skeletal collection built by the authors and housed at Irkutsk State University in Russia. Some additional identifications were made using the comparative collection in the Department of Anthropology of the University of Alberta and medieval cattle specimens provided to us by Irkutsk State Technological University. Following taxonomic determinations, all specimens were examined for evidence of human modification. Just over 7 percent of the total remains were burnt (1624 specimens), butchery marks were observed on 287 specimens, and tool production (e.g., grinding and polishing) marks were found on only 19 specimens. Very little non-human bone modification was observed: only 40 specimens have gnaw marks or tooth punctures, all of which appear to be from wolf or dog-sized carnivores.

The faunal assemblage at Sagan-Zaba is quite diverse and includes both wild and domestic fauna, including a significant number of aquatic species (Table 1). Note that all percentages offered here reflect the exclusion of fauna believed to be intrusive (small burrowing animals represented by relatively complete skeletons including Citellus undulates, Muridae, and undifferentiated small Rodentia). Baikal seal are the most abundant of the mammal remains at the site, accounting for 29 percent of the identified specimens by NISP, and were found in all layers. Next in abundance are domesticated fauna, including horse (Equus spp.), cattle (Bos spp.), and sheep/goats (Ovis/Capra), which compose 18 percent of the identified specimens. Wild cervids account for roughly 5 percent of the identified mammals and were also present in all layers. Roe deer (Capreolus pygargus) are the most abundant of this group, followed by red deer (Cervus elaphus); only a single specimen of moose (cf. Alces alces) was identified. Rodents and small carnivores compose relatively small percentages of the identified mammals and include hare (Lepus timidus), beaver (Castor fiber), marmot (Marmota spp.), sable (Martes zibellina), red fox (Vulpes vulpes), and otter (Lutra lutra). Birds too are quite rare and identified specimens include undifferentiated teal or duck (Anas spp.) and hawk (Buteo cf. buteo).

Fish remains were found in all layers, with a total of 1230 specimens being identified; 99 percent of these were found during sieving of cultural deposits. The most abundant are the salmonids (grayling-Thymallus articus, and whitefishes- 
Coregonus spp.), but sturgeon (Acispenser baeri baicalensis), roach (Rutilis rutilis lacustris), dace (Leuciscus leuciscus baicalensis), pike (Esox lucius), and perch (Perca fluviatilis) are also present. Grayling (two subspecies) and whitefishes (two species) are commonly found in the colder, deeper areas of the lake, including the waters immediately adjacent to the site. The remainder of the identified faunal $(0.8 \%$ of the total) are likely to be intrusive or non-food taxa and include small numbers of mice, rats, Eurasian ground squirrel (Citellus undulates), small birds of sparrow size, and very small mollusks. Overall, all the taxa identified can be found in the local environments surrounding the site today, the exception being the beaver, which was extirpated here more than 100 years ago (Nekipelov et al. 1965).

\section{TRENDS IN SUBSISTENCE PATTERNS AT SAGAN-ZABA}

The late Holocene faunal sample from Sagan-Zaba provides a glimpse of basic subsistence practices among pastoralists inhabiting Priol'khon'e over the last 3000 years or so (noting of course the possibility for some mix of materials from pastoralists and hunter-gatherers in the lowermost layer considered here). Overall, these practices can be characterized as a mix of pastoralism with hunting and fishing of wild terrestrial and aquatic fauna. Key domesticated animals here were clearly sheep, cattle, horses, and goats. This overall pattern in the types of animal raised and hunted is consistent with the information known from previous ethnohistoric and archaeological data. However, there are visible diachronic patterns in the relative abundances of taxa consumed at Sagan-Zaba that reveal finer details about the development of pastoralist economies in this region. To explore these changes in relative faunal abundances, we have constructed several indices. Such indices provide a relatively simple way of examining the diachronic frequency of groups of fauna relative to one another and are now commonly used in zooarchaeology in many areas of the world.

Perhaps the most revealing indices for the Sagan-Zaba data show trends in the relative frequency of domesticated animals through time. Our first index is the domesticates index, and was calculated by taking the total number of domesticates divided by the sum of the number of domesticates and wild mammalian fauna. ${ }^{2}$ Where the index value approaches 1.0, the higher the frequencies of domesticates relative to wild fauna; as the index approaches 0 , wild mammals increase in relative abundance to domesticates. Figure 5 shows this index plotted by layer for the Sagan-Zaba analytical units. A major increase can be seen in the relative abundance of domesticates between the IIIB and IIIA layers, while Layer I/II has essentially the same relative abundance of domesticates to wild fauna as seen in Layer IIIA. Notably, even in the two layers with comparatively high domesticate values, these reach only to just below 0.5 indicating that hunting continued to form a significant part of subsistence activities long after pastoralists had arrived. When an index comparing the relative abundance of just wild cervids to domesticates is plotted on the same graph (Fig. 5), a very similar trend appears: wild ungulates sharply drop in relative abundance to domesticates between Layers IIIB and IIIA and then increase very slightly in Layers I/II. Historically, wild cervid meat made a major contribution to diets of Buriats and other Cis-Baikal pastoralists (Mikhailov 2006; Zhambalova 1991). The major component of this element of the diet was roe deer meat, which historically was considered desirable 


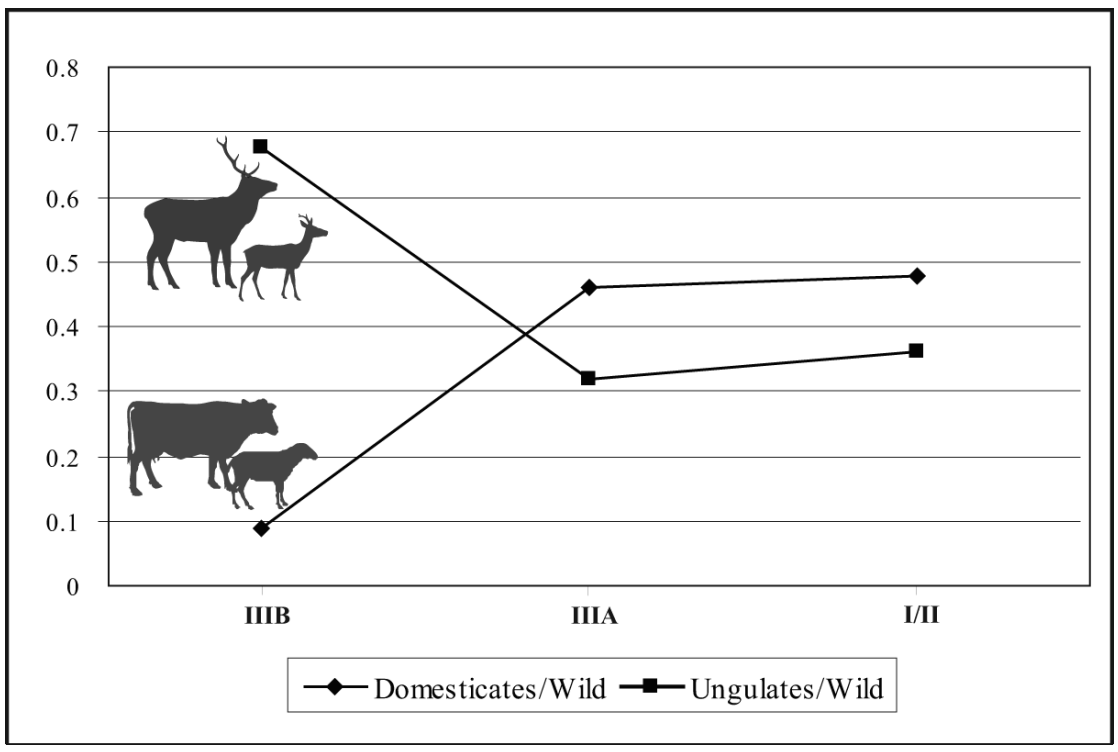

Fig. 5. Plot of the domesticates index and the cervids index for the three analytical units.

during all seasons of the year (Zhambalova 1991). High relative abundances of roe deer relative to all other wild taxa also have been noticed at medieval settlements on the Angara River tributaries (Ermolova 1979; Klemet'ev and Nikolaev 2007). Notably, the Ol'khon Island sites Tyshkine II/III just to the north contain primarily the remains of domesticates and seals, but only trace amounts of red deer and no roe deer whatsoever (Goriunova et al. 2007b). It is possible these wild ungulates were rarer on the island than on the adjacent mainland, or at least were less accessible from Tyshkine than at Sagan-Zaba.

The majority of the domesticated fauna at Sagan-Zaba are caprines and cattle, and their relative abundances also vary by layer (Table 1 ). To examine these patterns, we calculate a cattle index where the number of cattle specimens is divided by the sum of the number of cattle specimens and other domesticates for each analytical unit. This index is plotted in Figure 6 against the caprine index, which is the number of sheep and/or goat specimens divided by the sum of the number of sheep, goat, and other domesticates. This figure shows that the relative frequency of cattle in the Late Holocene deposits gradually increases through time while sheep and goats gradually decline in relative abundance. In other words, the first pastoralists at Sagan-Zaba Cove probably relied far more heavily on sheep and goats than cattle, but through time cattle became relatively more important. The tendency of increasing the proportion of cattle in the stock has been noticed by local ethnographers who pointed out that such trends occurred among the Buriats in historic times as a result of increasing population and decreasing mobility following Russian settlement of the region (Zhambalova 2004). Our cattle index indicates that this historically documented pattern follows a trend with much greater depth, perhaps beginning as early as the late Bronze or early Iron Ages. This likely indicates that the first pastoralists inhabiting Sagan-Zaba utilized a herding and mobility strategy that involved more residential moves, relatively 


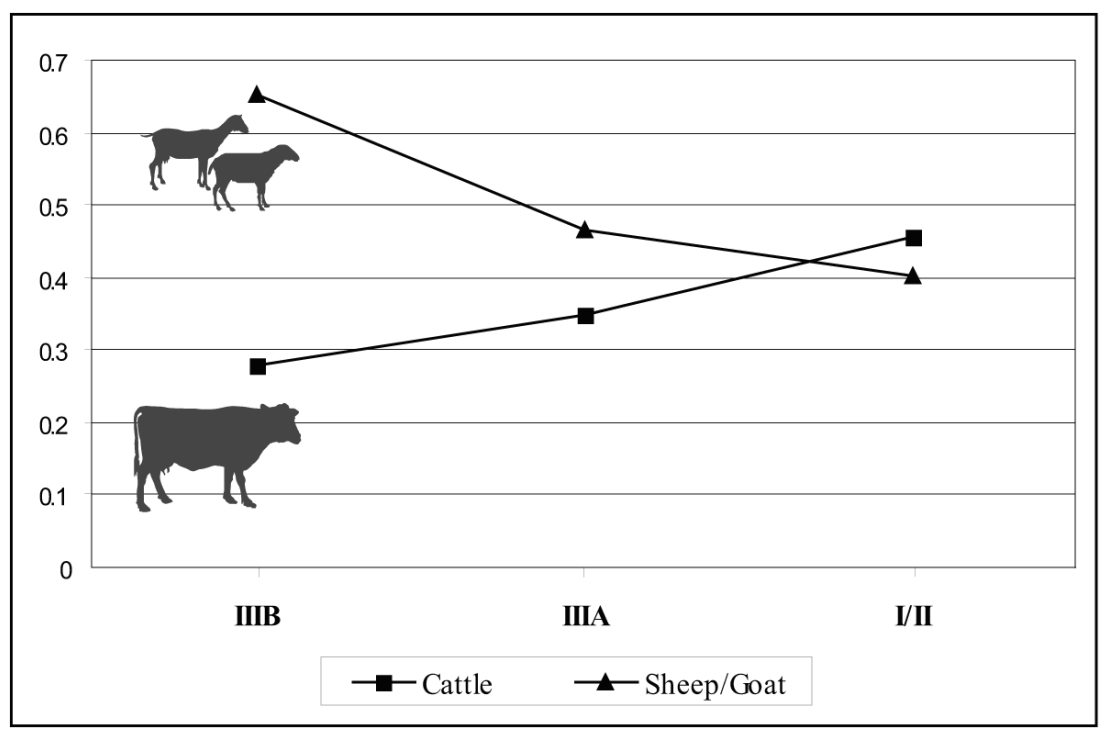

Fig. 6. Plot of the cattle and caprine indices for the three analytical units.

fewer cattle, and they had less capacity for providing winter forage than did later pastoralists of the area.

Another pattern evident in the data is that horse remains were not as frequently found at Sagan-Zaba as the other domesticates (Table 1). As mentioned earlier, horses are the iconic animals of pastoralists and were used for transport, warfare, hunting, but were also eaten. Perhaps the relatively low abundances of this animal at Sagan-Zaba indicate that horses were relatively rare and highly valued here, and that they were only occasionally slaughtered for consumption. Unlike at Sagan-Zaba, bones of horse and cattle appear to dominate the archaeological assemblages from the Angara River tributaries while caprines remains there are relatively less abundant (Ermolova 1978; Klement'ev and Nikolaev 2007). Their rarity at Sagan-Zaba may also be explained by the environmental characteristics of Priol'khon'e compared to the other Cis-Baikal steppe patches. Historically, Priol'khon'e has been characterized as a somewhat marginal steppe patch due to its aridity and poor soils, and it was argued that these conditions forced local Buriat populations to focus on raising sheep and to substantially supplement their diets through sealing, fishing, and hunting of wild ungulates (Georgi 1777; Zhambalova 2004). Ethnographic data on the Ol'khon Buriats before the Soviet period also suggest relatively low abundance of horses here compared to other domesticates. For example, Buriats on the island are reported to have had an average of 30-40 cattle, 50-60 sheep, as well as an unspecified number of goats, but only 3-5 horses (with a few exceptional cases of individuals with 10-20 horses; Zhambalova 2004 : 97).

One of the most interesting aspects of Baikal pastoralists is that they are the only pastoralists known to us to regularly hunt seals. Seal hunting is still practiced throughout the year by Buriats on Lake Baikal, and this hunting provides them with meat, furs, and most importantly fat/blubber $(30-40 \mathrm{~kg}$ from one animal; 
Toporkov 1926). Most sealing appears to have occurred when the lake was ice covered. Ethnographically documented hunting techniques include clubbing basking animals, using dogs to locate breathing holes and employing nets below the ice, and harpooning in various contexts (Georgi 1777; Levin 1897; Pallas 1788; Zhambalova 1984). During more recent times the most important season for sealing is the spring when seals are found in large concentrations sun basking, and can be clubbed. Notably, most of the commercial seal hunting conducted from the beginning of the eighteenth to the twentieth century involved the use of rifles by local Buriats, Evenks, and Russians (Levin 1897), which allowed seals to be more easily taken from boats during seasons of open water (Toporkov 1926).

It is noteworthy that Sagan-Zaba Cove was used by hunter-gatherers as a sealing camp throughout the Middle Holocene and continued to be used for this task by late Holocene pastoralists. Our preliminary analyses of the Neolithic (Middle Holocene) layers at Sagan-Zaba indicate that seals likely account for over 90 percent of the identifiable specimens from these earlier time periods. While not as dominant in the Late Holocene, seals continue to be the most abundant of the identified mammals at the site during the latter periods of its occupation. To examine the relative importance of seals to domesticated fauna, we calculated a seal index by dividing the number of seals per analytical unit by the sum of the total number of seals plus the total number of domesticates (Fig. 7). This index indicates that seals were far more abundant than domesticated fauna in the lowermost layer but declined sharply in relative abundance as domesticates increased in relative abundance in Layer IIIA. Seal use shows only a very small decrease from Layer IIIA to Layers I/II. Note that even within these layers of a later date the seal index is just below 0.5 , indicating that seals remained nearly as abundant as all domesticates combined. This clearly indicates that when Sagan-Zaba was

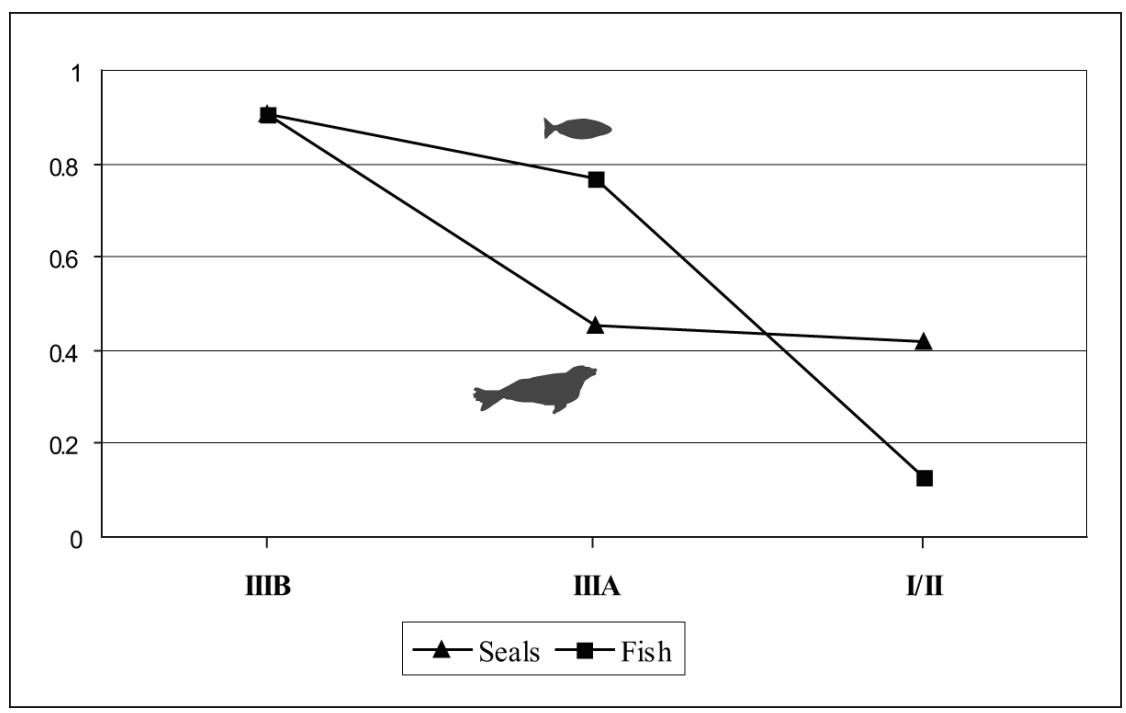

Fig. 7. Plot of the seal index and fish index for the three analytical units. 
routinely being used for pastoralism in the early Iron Age, people continued to commonly hunt seals from the site, although their relative importance sharply decreased compared to the Bronze Age occupation (which may represent a mix of hunter-gatherer and pastoralist materials).

Fish remains were also recovered in some abundance from Sagan-Zaba (Table 1). Our final index is designed to examine the relative abundance of fish remains to domesticate remains. This fish index is the number of identified fish remains (identified at least to the family level) divided by the sum of the number of fish remains and the number of domesticates (Fig. 7). The fish index is the only index calculated here that shows a relatively large change in relative abundance from Layers IIIA to I/II. While fish remains were far more frequent than those from domesticates in Layer IIIB, they decline only slightly in relative abundance in Layer IIIA but show a sharp drop in Layers I/II. Clearly fish were relatively less important during the Early Mongolian Time than in any earlier period during the late Holocene. This pattern contrasts with that of the seal index and the wild ungulate index, both of which show sharp dropoffs between Layers IIIB and IIIA.

It has been generally assumed that most pastoralist populations inhabiting CisBaikal and adjacent territories looked upon fish with some disapproval and only fished when they had few other options (Mikhailov 2006). Such attitudes were apparently shared by the Buriats, Mongols, Yakuts, and other nomadic pastoral groups (Tokarev and Gurvich 1956; Vyatkina 1956). The only Buriat group that historically engaged in seasonal fishing parallel to their pastoral activities is that inhabiting the shores of Lake Baikal, including Priol'khon'e. However, this fishing was primarily a part of a market economy, where omul' (Coregonus autumnalis migratorius) were exchanged for other food products from the late eighteenth to the early twentieth century (e.g., Levin 1897; Viatkina 1969; Zalkind 1970). Notably, fish remains have never been reported among the faunal assemblages at other late Holocene sites in Cis-Baikal, but this is likely due to the lack of sieving during excavations. Recall that in our current sample, 99 percent of the fish remains were recovered during sieving. Based on the Sagan-Zaba data, it seems likely that fishing was always a part of pastoralists' subsistence practices in Priol'khon'e, although its importance significantly declined during the Early Mongolian Time.

\section{CONCLUSIONS AND DIRECTIONS FOR FUTURE STUDIES}

Sagan-Zaba is the first late Holocene site in Cis-Baikal to be screened with finemeshed sieves and to be systematically studied by zooarchaeologists. Our analyses of its faunal assemblage provide a series of new insights on pastoralist subsistence practices in an area where previous investigations of late Holocene sites have largely focused on mortuary materials. First, the earliest pastoralists at Sagan-Zaba arrived with classic Central Asian domesticates, namely sheep, goats, cattle, and horses. Sheep and goats were the most abundant of these, but cattle became relatively more common through time, perhaps as a result of increasing sedentism and the ability to provide these animals with winter fodder and shelter. Horses do not appear to have been as abundant as the other domesticates, a pattern documented historically for the Priol'khon'e. Second, seal hunting was of major importance at Sagan-Zaba throughout the late Holocene, despite the presence of domesticated 
stock. Sealing, however, was not new to Sagan-Zaba with the arrival of pastoralists but instead was first practiced here thousands of years earlier by huntergatherers. Hunting of wild ungulates and small fur-bearing animals was also common throughout the late Holocene at Sagan-Zaba and the primary dietary contributors were roe deer and red deer.

Fishing was clearly a part of subsistence practices at the site throughout the latter portion of its occupation. Fishing was previously archaeologically undocumented for the region's pastoralist groups, perhaps due to lack of sieving during previous excavations. Our data suggest that the historically documented fishing by local Buriats for the purposes of market exchange was not completely the result of Russian-period settlement of the region. Instead, some fishing by pastoralists occurred in Cis-Baikal long prior to the modern era. Overall, all periods of pastoral occupation of Sagan-Zaba witnessed subsistence patterns that were clearly of a mixed nature, involving domesticates, hunting of wild terrestrial and aquatic mammals, and fishing. Finally, based on the limited amount of comparative data, late Holocene subsistence patterns at Sagan-Zaba were considerably more diverse than in adjacent steppe patches in Cis-Baikal. This may have been due to the rather marginal steppe environment of Priol'khon'e compared to adjacent regions, which placed limits on pastoral production and in turn required that a broader spectrum of subsistence resources be regularly exploited.

Future zooarchaeological research on late Holocene subsistence practices in Cis-Baikal should reveal if the trends observed at Sagan-Zaba are truly characteristic of the entire region or are solely indicative of practices in Priol'khon'e during this time period. We believe the data presented here further illustrate the utility of sieving excavated site sediments dating to the late Holocene-a whole class of animals (fishes) has appeared for the first time in the region's late archaeological record as a result of applying recovery methods commonly used in other areas of the world. Furthermore, the indices developed here could be applied to assemblages throughout the region (when they are well dated and quantified) and likely would provide significant insights on pastoralist subsistence practices that have previously escaped notice. Future work might also focus on reconstructing butchery practices involving domesticates. Significant ethnographic and ethnohistoric data exists on both Buriat and Mongol butchery of such animals (e.g., Boyle 1965; Galdanova 1992), and it would be interesting to compare these patterns with those documented in the archaeological records of the various Cis-Baikal pastoralist groups as well as other groups in Siberia and Central Asia. Finally, it should prove highly worthwhile to examine human skeletal stable isotope signatures from the region's pastoralists as another means of assessing diachronic patterns in Late Holocene subsistence practices, diets, and mobility. (See Haverkort et al. 2008, Katzenberg and Weber 1999, and Katzenberg et al. 2008, for such studies on Middle Holocene Cis-Baikal human remains.) When all of these data sets can be integrated, a much fuller understanding of pastoral adaptations in this portion of eastern Siberia will be possible.

\section{ACKNOWLEDGMENTS}

The funding for this research was provided by a Social Science and Humanities Major Collaborative Research grant to the Baikal Archaeological Project team and a 
Canadian Circumpolar Institute grant to T. Nomokonova. The authors would like to thank all participants of the Russian-Canadian expedition at Sagan-Zaba II conducted during 2006-2008, especially its co-supervising team of Dr. H. McKenzie and Dr. G. A. Vorob'eva. These excavations were carried out under an excavation permit given to Dr. A .G. Novikov. Special thanks is offered to Natal'ia Batrakova for her enormous help in quantification of faunal remains and Alexei Klement'ev for providing access to a comparative collection of medieval cattle skeletons at Irkutsk State Technical University.

\section{NOTES}

1. Genus and species designations are not provided for these publications because such designations were not consistently provided in the sources.

2. Note that all indices calculated here exclude specimens deemed to be intrusive.

\section{REFERENCES CITED}

Anthony, D. W.

2007 The Horse, the Wheel and Language: How Bronze Age Riders from the Eurasian Steeps Shaped the Modern World. Princeton and Oxford: Princeton University Press.

AseEv, I. V.

1980 Pribaikal'e v Srednie Veka po Arkheologicheskim Dannym. Novosibirisk: Nauka [in Russian].

2003 Ingo-Vostochnaia Sibir'v Epokhu Kamnia $i$ Metalla. Novosibirisk: Izdatel'stvo Instituta Arkheologii i Etnografii SO RAN [in Russan].

BARFIELD, T.

1993 The Nomadic Alternative. New Jersey: Prentice Hall Inc.

Batueva, I. B.

1989 Skotovodstvo v sisteme traditsionogo khoziaistva Buriat, in Buriatia XVII-nachala XX v.: 51-68. Novosibirsk: Nauka [in Russian].

Boyle, J. A.

1965 A form of horse sacrifice amongst the 13th and 14th century Mongols. Central Asiatic Journal X (3-4): 145-150.

Curtin, J.

1909 A Journey in Southern Siberia. Boston: Bibliobazaar.

Dashibalov, B. B.

1995 Arkheologicheskie Pamiatniki Kurykan i Khori. Ulan-Ude: BNTS SO RAN [in Russian].

Ermolova, N. M.

1978 Teriofauna Doliny Angary v Pozdnem Antropogene. Novosibirsk: Nauka [in Russian].

Galdanova, G. P.

1992 Zakamenskie Buriaty: Istoriko-Etnograficheskie Ocherki (Vtoraia polovina XIX-Pervaia polovina $X X v$.). Novosibirsk: Nauka [in Russian].

GeOrGi, I. G.

1777 Opisanie vsekh $v$ Rossiiskom Gosudarstve Obitaiushchikh Narodov, takzhe ikh Zhiteiskikh Obriadov, Very, Obyknovenii, Zhilishch, Odezhd i Prochikh Dostopriamichatel'nostei. Part 3, Spb. [in Russian].

Goriunova, O. I., and A. G. Novikov

1997 Kompleksy zheleznogo veka mnogosloinogo poseleniia Katun' I. Gumanitarnye Nauki Sibiri 3: 27-35 [in Russian].

Goriunova, O. I., A. G. Novikov, G. A. Vorob'eva, R. J. Losey, T. IU. Nomokonova, and

L. A. Orlova

2007a Prodolzhenie raskopok Rossiisko-Kanadskoi ekspeditsii v bukhte Sagan-Zaba na Baikale, in Problemy Arkheologii, Etnografii, Antropologii Sibiri $i$ Sopredel'nykh Terrotorii, Vol. 13: 212-215. Novosibirsk: Isd-vo IAiE SO RAN [in Russian]. 
Goriunova, O. I., N. D. Ovodov, and A. G. Novikov

$2007 b$ Analiz faunisticheskikh materiialov s mnogosloinogo poseleniia Tyshkine III (oz. Baikal), in Severnaia Evraziia v Antropogene: Chelovek, Paleotekhnologii, Geoekologiia, Etnologiia $i$ Antropologiia. Vol. 1: 168-174. Irkutsk: Izd-vo "Ottisk" [in Russian].

Goriunova, O. I., And E. A. Pudovkina

1995 Mogil'nik Elga VII i ego mesto v periodizatsii zheleznogo veka Priol'khon'ia, in Baikal'skaia Sibir'v Drevnosti Vol. 2, Part 2: 154-174. Irkutsk: Izd-vo Irkutskogo Gosudarstvennogo Pedagogicheskogo Unversiteta [in Russian].

Goriunova, O. I., AND V. V. Svinin

1995 Ol'khonskii Raion: Materialy k Svodu Pamiatnikov Istorii i Kul'tury Irkutskoi Oblasti. Vol. 1: Ostrov Ol'khon. Irkutsk: Arkom [in Russian].

1996 Ol’khonskii Raion: Materialy k Svodu Pamiatnikov Istorii i Kul'tury Irkutskoi Oblasti. Vol. 2: Materikovyi Uchastok: ot Mysa Elokhin do Mysa Ulan. Irkutsk: Arkom [in Russian].

2000 Ol'khonskii Raion: Materialy k Svodu Pamiatnikov Istorii i Kul'tury Irkutskoi Oblasti. Vol. 3: Materikovyi Uchastok: ot Mysa Ulan do Reki Bol'shaia Bugul'deika. Irkutsk: Arkom, [in Russian].

Goriunova, O. I., And G. A. Vorob'eva

1986 Osobennosti prirodnoi obstanovki i material'naia kul'tura Priol'khon'ia v golotsene, in Paleoeconomika Sibiri: 40-53. Novosibirsk: Nauka [in Russian].

Grousset, R.

2005 The Empire of the Steppes: A History of Central Asia. New Brunswick, NJ: Rutgers University Press.

Haverkort, C. M., A. Weber, M. A. Katzenberg, O. I. Goriunova, A. Simonetti, and R. A. Creaser

2008 Hunter-gatherer mobility strategies and resource use based on strontium isotope $\left({ }^{87} \mathrm{Sr} /\right.$ ${ }^{86} \mathrm{Sr}$ ) analysis: A case study from Middle Holocene Lake Baikal, Siberia. Journal of Archaeological Science 35 : 1265-1280.

IMENOKHOEV, N. V.

1992 Rannemongol'skaia arkheologicheskaia kul'tura, in Arkheologicheskie Pamiatniki Epokhi Srednevekov'ia Buriatii i Mongolii: 23-48. Novosibirsk: Nauka [in Russian].

ISHJAMTS, $\mathrm{N}$.

1994 Nomads in Eastern Central Asia, in History of Civilizations of Central Asia, vol. 2: 151-169. Paris: Unesko Publishing.

Kasparov, A. K.

1991 Ostatki mlekopitaiushchikh iz srednevekovogo gorodishcha Mankhai v Pribaikal'e, in Paleoetnologicheskie Issledovaniia na Iuge Srednei Sibiri: 147-156. Irkutsk: Irkutskii Gosudarstvennyi Universitet [in Russian].

Katzenberg, M. A., O. I. Goriunova, and A. Weber

2008 Paleodiet reconstruction of Bronze Age Siberians from the mortuary site of KhuzhirNuge XIV, Lake Baikal. Journal of Archaeological Science 36(3) : 663-674.

Katzenberg, M. A., ANd A. Weber

1999 Stable isotope ecology and paleodiet in the Lake Baikal region of Siberia. Journal of Archaeological Science 26:651-659.

KhARINSKII, A. V.

1995 O poiavlenii skotovodstva v Predbaikal'e, in Tret'i Istoricheskie Chteniia Pamiati M.P. Griaznova, part II: 95-98. Omsk: Izdatel'stvo Omskogo Gosudarstvennogo Universiteta [in Russian].

2001 a Predbaikal'e v kon. I tys. do n.e.—ser. II tys n.e.: Genesis Kultur i Ikh Periodizatsiia. Irkutsk: Izdatel'stvo Irkutskogo Gosudarstvennogo Teknicheskogo Universiteta [in Russian].

$2001 b$ Priol'khon'e v Srednie Veka: Pogrebal'nye Kompleksy. Irkutsk: Izdatel'stvo Irkutskogo Gosudarstvennogo Teknicheskogo Universiteta [in Russian].

2005 Zapadnoe poberezh'e ozera Baikal v I tys. do n.e.- I tys. n.e., in Izvestiia Laboratorii Drevnikh Tekhnologii IrGTU, vol. 3: 198-215, ed. A. V. Kharinskii. Irkutsk: Izdatel'stvo Irkutskogo Gosudarstvennogo Tekhnicheskogo Universiteta, [in Russian].

Klement'ev, A. M., and V. S. Nikolaev

2007 Faunisticheskaia kharakteristika srednevekovogo poseleniia Totok. In Izvestiia Laboratorii Drevnikh Tekhnologii IrGTU, vol. 5: 175-183, ed. A. V. Kharinskii. Irkutsk: Izdatel'stvo Irkutskogo Gosudarstvennogo Tekhnicheskogo Universiteta, [in Russian]. 
LEVIN, N. P.

1897 Rybolovstvo i rybopromyshlennost' na Ol'khone, in Izvestiia Vostochno-Sibirskogo Otdela Imperatorkogo Russkogo Geograficheskogo Obshchestva, vol. 28: 44-81. Irkutsk [in Russian].

Mikhailov, V. A.

2006 Traditsionnye Promysly Buriat: Okhota, Rybolovstvo (XVIII-nachalo XX veka). Part 2. UlanUde: Izd-vo OAO "Respublikanskaia Tipografiia” [in Russian].

Nekipelov, N. I., Sviridov, N. S. And A. A. Tomilov

1965 Zivotnyi Mir. In Predbaikal'e i Zabaikal'e, pp. 282-323. Moskva: Nauka [in Russian].

Nikolaev, V. S.

2004 Pogrebal'nye Kompleksy Kochevnikov Inga Srednei Sibiri v XII-XIV Vekakh. VladivostokIrkutsk: Izd-vo Instituta Geografii SO RAN [in Russian].

Nomokonova, T. IU.

2003 Kompleksy pozdnego zheleznogo veka na poberezh'e Chivyrkuiskogo zaliva ozera Baikal, in Sotsiogenez Severnoi Azii: Proshloe, Nastoiashchee, Budushchee: 102-107. Irkutsk: Irkutskii Tekhnicheskii Universitet [in Russian].

2005 Ornamentatsiia srednekovykh sosudov Priol'khon'ia (oz.Baikal), in Izvestiia Laboratorii Drevnikh Tekhnologii, vol. 3: 221-230, ed. A. V. Kharinskii. Irkutsk: Irkutskii Gosudarstvennyi Tekhnicheskii Universitet [in Russian].

Nomokonova, T. IU., and O. I. Goriunova

2000 Keramicheskie kompleksy poseleniia Khuzhir-Nuge XV (ozero Baikal), in Ecologiia Baikala i Pribaikal'ia: 22-23, Irkutsk: Irkutskii Gosudarstvennyi Universitet [in Russian].

Nomokonova, T. IU., R. J. Losey, and O. I. Goriunova

2007 Vliianie metodov polevykh rabot $\mathrm{i}$ tafonomicheskikh protsessov na kostnye ostatki ryb s mnogosloinoi stoianki Ityrkhei (Maloe More, Ozero Baikal), in Izvestiia Laboratorii Drevnikh Tekhnologii, vol. 5: 154-167, ed. A. V. Kharinskii. Irkutsk: Irkutskii Gosudarstvennyi Tekhnicheskii Universitet [in Russian].

Nomokonova, T., R. Losey, O. I. Goriunova, A. Weber, H. McKenzie, and A. G. Novikov

2009 Perspektivy zooarkheologicheskikh issledovanii v bukhte Sagan-Zaba na Baikale. Vestnik Novosibirskogo Gosudarstvennogo Universiteta, Seriia: Istoriia, Filologiia 8 (5: Arkheologiia i Etnografiia): 116-122 [in Russian].

Okladnikov, A. P.

1959 Ancient Population of Siberia and Its Cultures. Cambridge: Peabody Museum.

1974 Petroglify Baikala-Pamiatniki Drevnei Kul'tury Narodov Sibiri. Novosibirsk: Nauka [in Russian].

Ovodov, N. D., And V. A. Panychev

1982 Fauna i radiouglerodnoe datirovanie neoliticheskoi stoianki Sagan-Zaba na Baikale, in Problemy Arkheologii i Etnografii Sibiri: 66-68. Irkutsk: Irkutskii Gosudarstvennyi Universitet [in Russian].

Pallas, P. S.

1788 Puteshestvie po Razlichnym Provintsiiam Rossiiskogo Gosudarstva. Vol. 3. Spb. [in Russian].

Pastukhov, V. D.

1993 Nerpa Baikala: Biologicheskie Osnovy Ratzional'nogo Ispol'zovaniia i Okhrana Resursov. Novosibirsk: Nauka [in Russian].

Pletneva, S. A.

1982 Kochevniki Srednevekov'ia. Moskva: Nauka [in Russian].

Rumiantsev, G. N.

1962 Proiskhozdnie Khorinskikh Buriat. Ulan-Ude: Buriatskoe Knizhnoe Izdatel'stvo [in Russian].

Stuiver, M., P. J. Reimer, And R. W. Reimer

2005 CALIB 5.0. [WWW program and documentation].

SVININ, V. V.

1976 Periodizatsiia arkheologicheskikh pamiatnikov Baikala. Izvestiia VSORGO SSSR 69:167-179 [in Russian].

Tokarev, S. A., And I. S. Gurvich

1956 The Yakuts, in The Peoples of Siberia: 243-304, ed. M. G. Levin and L. P. Potapov. Chicago: University of Chicago Press. 
Toporkov, N. N.

1926 Ekonomicheskoe znachenie nerpich'ego promysla. Severnaia Aziia 5-6:63-75 [in Russian].

Tsybiktarov, A. D.

1998 Kul'tura Plitochnykh Mogil Mongolii i Zabaikal'ia. Ulan-Ude: Isd-vo Buriatskogo Gosuniversiteta [in Russian].

1999 Buriatiia v Drevnosti: Istoria s Drevneishikh Vremen do XVII veka. Ulan-Ude: Isd-vo Buriatskogo Gosuniversiteta [in Russian].

Turkin, G. V.

2004 Pogrebal'naia obriadnost' naseleniia Predbaikal'ia v kontse II-I tys.do.n.e. (k voprosy ob etnokul'turnoi situatsii, in Tsentral'naia Asiia i Pribaikal'e v drevnosti, vol. 2: 82-92. UlanUde: Isd-vo BGU [in Russian].

Vorob'eva, G. A., and O. I. Goriunova

1997 Ranii-srednii golotsen Priol'khon'ia (v svete novykh dannykh), in Problemy Arkheologii, Etnografii, Antropologii Sibiri i Sopredel'nykh Territorii, vol. 3: 29-35. Novosibirsk: Izdatel'stvo IAEt SO RAN [in Russian].

VIATKINA, K. V.

1969 Ocherki Kul'tury i Byta Buriat. Leningrad: Nauka [in Russian].

VYATKINA, K. V.

1956 The Buryats. In The Peoples of Siberia: 203-242, ed. M. G. Levin and L. P. Potapov. Chicago: University of Chicago Press.

Weber, A., D. W. Link, O. I. Goriunova, and A. K. Konopatskit

1998 Patterns of prehistoric procurement of seal at Lake Baikal: A zooarchaeological contribution to the study of past foraging economies in Siberia. Journal of Archaeological Science $25: 215-227$.

Weber, A.W., D. W. Link, And M. A. Katzenberg

2002 Hunter-gatherer culture change and continuity in the Middle Holocene of the Cis-Baikal, Siberia. Journal of Anthropological Archaeology $21: 230-299$.

ZALKIND, E. M.

1970 Obshchestvennyi Stroi Buriat v XVIII-pervoi polovine XIX v. Moskva: Nauka [in Russian].

Zhambalova, S. G.

1984 Okhota na nerpu u Ol'khonskikh buriat, in Etnicheskaia Istoriia i Kul'turno-bytovye Traditsii $v$ Buriatii: 97-107. Ulan-Ude: Akademiia Nauk SSSR [in Russian].

1991 Traditsionnaia Okhota Buriat. Novosibirsk: Nauka [in Russian].

2000 Profal'nyi i Sakral'nyi Miry Ol'khonskikh Buriat. Novosibirsk: Nauka [in Russian].

2004 Okhota na nerpu u Ol'khonskikh buriat, in Buriaty, chapter 3: Skotovodstvo: 93-117. Moskva: Nauka [in Russian].

\begin{abstract}
Roughly 3000 years ago, nomadic pastoralists began to arrive in the Cis-Baikal region of eastern Siberia. While the archaeological record of these groups is quite extensive, most research on pastoralists here has focused on mortuary traditions while questions about subsistence practices have been left largely unaddressed. Few habitation sites from the late Holocene here contain stratified deposits, and virtually none have been subject to modern excavation methods or zooarchaeological analyses. We present new faunal data from the recently excavated Sagan-Zaba II site located on the west coast of Lake Baikal. This site offers a unique opportunity to examine diachronic patterns in diet and subsistence practices of local pastoralists. It contains stratified deposits associated with different periods of pastoralist occupation spanning much of the late Holocene. Significantly, it is the first site of this period in the region to be screened with fine-meshed sieves and to be systematically studied by zooarchaeologists. The results of our research reveal a series of new insights on pastoralist subsistence practices. First, the primary domesticates in all periods were sheep, goats, cattle, and horses. Cattle appear to increase through time at the site while horses remained relatively rare. Second, pastoralists at Sagan-Zaba regularly
\end{abstract}


hunted Lake Baikal's freshwater seals, long after the introduction of domesticated livestock. Third, hunting of terrestrial mammals, particularly roe deer and red deer, was also common at the site. Finally, our data demonstrate that pastoralists here also regularly fished. This subsistence practice was previously unrecognized in the region, likely due to lack of sieving of sites. Furthermore, these data suggest that historically documented fishing by modern local pastoralists and increases in sedentism were not completely the result of Russian-period settlement of the region but instead were occurring in Cis-Baikal long prior to the modern era. KeYwords: Siberia, Lake Baikal, nomadic pastoralists, late Holocene, Iron Age, subsistence, zooarchaeology. 